\title{
Simple RP-HPLC method for determination of triple drug combination of valsartan, amlodipine and hydrochlorothiazide in human plasma
}

\author{
RITESH N. SHARMA ${ }^{1 *}$ \\ SHYAM SUNDER PANCHOLI ${ }^{2}$ \\ ${ }^{1}$ S. K. Patel College of Pharmaceutical \\ Education and Research, Ganpat \\ University, Mahesana-Gozaria Highway \\ Kherva Dist. Mahesana-382711 \\ Gujarat, India \\ 2 Babria Institute of Pharmacy, Varnama \\ Vadodara-391240, Gujarat, India
}

\begin{abstract}
A simple RP-HPLC method for the quantification of valsartan (VAL), amlodipine (AML) and hydrochlorothiazide (HCT) in human plasma was developed and validated. VAL, AML and HCT were resolved using a Gemini $\mathrm{C}_{18}$ column and mobile phase gradient starting from 20 $\%$ acetonitrile and $80 \% 10 \mathrm{mmol} \mathrm{L}^{-1}$ ammonium formate $(V / V$, pH $3.5 \pm 0.2$, by formic acid) to $70 \%$ acetonitrile and $30 \% 10 \mathrm{mmol} \mathrm{L}^{-1}$ ammonium formate, over $20 \mathrm{~min}$ utes, with a flow rate of $1 \mathrm{~mL} \mathrm{~min}^{-1}$. The samples were purified by protein precipitation and extraction. Telmisartan was used as internal standard. The method was validated according to USFDA and EMEA guidelines with good reproducibility and linear responses $R=0.9985$ (VAL), 0.9964 (AML), and 0.9971 (HCT). RSDs of intra- and inter-day precision ranged 2.2-8.1 and 4.6-11.7\%, respectively, for all three drugs. Mean extraction recoveries of three QCs for the triple drug combination were 76.5 (VAL), 72.0 (AML) and 73.0 (HCT) \% for human plasma. Although the LC-MS/MS method is more sensitive than HPLC, HPLC is still suitable for preliminary pharmacokinetic study. The experiments performed demostrated that simultaneous determination of all components of the triple drug combination in human plasma can be done by this method. Proposed method can be also used for guidance to the LC-MS/MS method.

Keywords: valsartan, amlodipine, hydrochlorothiazide, triple drug combination, plasma, RP-HPLC, preliminary pharmacokinetic
\end{abstract}

Hypertension is emerging as one of the most significant health complications in recent years (1). There has been a marked increase in the use of combinations of antihypertensive drugs as well with complementary mechanisms of action, with the aim of reducing blood pressure levels more rapidly and improving treatment compliance. The

\footnotetext{
*Correspondence; e-mail: riteshn.sharma@gmail.com
} 
R. N. Sharma and S. S. Pancholi: Simple RP-HPLC method for determination of triple drug combination of valsartan, amlodipine and hydrochlorothiazide in human plasma, Acta Pharm. 62 (2012) 45-58.

2009 reappraisal of the European Society of Hypertension/European Society of Cardiology Guidelines recommends the use of a triple drug combination that combines a calcium channel blocker, an angiotensin II receptor blocker and a thiazide diuretic as an efficacious combination for the management of hypertension with high or very high risk. The combination of valsartan (VAL), amlodipine (AML) and hydrochlorothiazide (HCT) achieved greater reductions in mean sitting diastolic and systolic blood pressure than VAL, AML or HCT in monotherapy, with favorable pharmacodynamic and pharmacokinetic profiles (2).

Valsartan, which is chemically described as $N$-(1-oxopentyl)- $N$-[[2-(1H-tetrazol-5-yl) [1,1-biphenyl]-4-yl]methyl]-L-valine (Fig. 1a) (3), is a nonpeptide drug reducing blood pressure by specifically blocking the action of angiotensin II on the angiotensin subtype-1 receptor. Peak plasma levels $\left(2-4 \mu \mathrm{g} \mathrm{mL}^{-1}\right)$ are reached after $2 \mathrm{~h}$ of oral administration $(160 \mathrm{mg})$ and then decline with a terminal half-life ranging $3-7 \mathrm{~h}(4,5)$. The drug is minimally metabolized and excreted largely (about $80 \%$ ) unchanged (6). Amlodipine is 3-ethyl-5-methyl ( \pm )-2-[(2-aminoethoxy)methyl]-4-(o-chlorophenyl)-1,4-dihydro-6-methyl-3,5-pyridinedicarboxylate, monobenzene sulphonate (Fig. 1b) and acts by inhibiting the entry of calcium ions to the vascular smooth muscle of the resistance arterioles. Direct relaxant effects cause reductions in peripheral vascular resistance and blood pressure. Hydrochlorothiazide, 6-chloro-1,1-dioxo-3,4-dihydro-2H-1,2,4-benzothiadiazine-7-sulfonamide (Fig. 1c), is a thiazide diuretic commonly used in combination with other antihypertensive agents, including angiotensin II receptor blockers (ARBs) (7). Hydrochlorothiazide is known to activate the renin-angiotensin-aldosterone system (RAAS), providing a strong rationale for the combination of an ARB with HCT (8).

Several HPLC and HPLC-MS methods have been described for the determination of $\operatorname{VAL}(1,9$ and 10), AML $(11,12)$ and HCT (13) alone in human plasma. There are also re-

a)

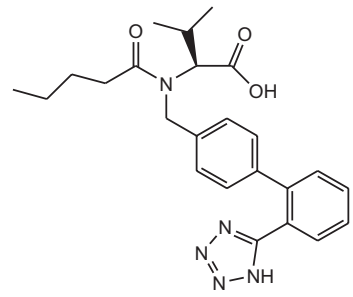

c)<smiles>NS(=O)(=O)c1cc2c(cc1Cl)NCNS2(=O)=O</smiles>

b)<smiles>CCOC(=O)C1=C(COCCN)NC(C)=C(C(=O)OC)C1c1ccccc1Cl</smiles>

d)

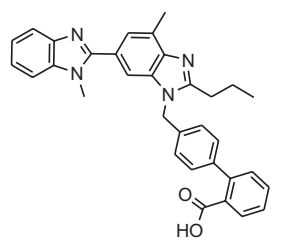

Fig. 1. Structures of: a) valsartan, b) amlodipine besylate, c) hydrochlorothiazide and d) telmisartan (IS). 
R. N. Sharma and S. S. Pancholi: Simple RP-HPLC method for determination of triple drug combination of valsartan, amlodipine and hydrochlorothiazide in human plasma, Acta Pharm. 62 (2012) 45-58.

ports of methods for simultaneous estimation of VAL and HCT in human plasma (14) and VAL and AML (15) in rat lever perfusion, but no method has been reported so far for simultaneous estimation of VAL, AML and HCT in human plasma. Hence, we aimed to develop and validate a simple RP-HPLC method for the triple drug combination of valsartan, amlodipine and hydrochlorothiazide in human plasma that could be used for pharmacokinetic studies and therapeutic drug monitoring.

\section{EXPERIMENTAL}

\section{Chemicals and materials}

VAL was procured as a gift sample from Dr. Reddy's Laboratory (India) while AML, TEL (IS) and HCT were obtained as gift samples from Torrent Pharma Ltd. (India). Methanol, acetonitrile and water of HPLC grade were supplied by Merck Chemicals Ltd. (India). Ammonium formate and formic acid of AR grade were procured from Spectrochem Pvt. Ltd. (India). Human blood plasma was obtained from the blood bank (India).

\section{Apparatus and chromatographic conditions}

Chromatographic separations were performed on a Shimadzu (Japan) HPLC system $\left(\right.$ LC-2010C $\left.C_{\mathrm{HT}}\right)$ using Gemini $\mathrm{C}_{18}(250 \times 4.6 \mathrm{~mm}$ i.d. $5 \mu \mathrm{m}$ particle size) column (Phenomenex $\left.{ }^{\circledR}, \mathrm{USA}\right)$, protected with a $\mathrm{C}_{18}\left(4 \times 2 \mathrm{~mm}\right.$ i.d.) precolumn, maintained at $35^{\circ} \mathrm{C}$. The mobile phase component ratio was managed using the LC Solution Software (Version 1.2) gradient mode from $20 \%$ acetonitrile and $80 \% 10 \mathrm{mmol} \mathrm{L}^{-1}$ ammonium formate $\left(V / V, \mathrm{pH} 3.5 \pm 0.2\right.$, by formic acid) to $70 \%$ acetonitrile and $30 \% 10 \mathrm{mmol} \mathrm{L}^{-1}$ ammonium formate over 20 minutes with a flow rate of $1 \mathrm{~mL} \mathrm{~min}^{-1}$. The sample $(40 \mu \mathrm{L})$ was injected with an auto sampler maintained at $15{ }^{\circ} \mathrm{C}$ and detection was carried out at 254 nm using a photodiode array (PDA) detector.

\section{Standard solutions}

Standard stock solutions $\left(100 \mu \mathrm{g} \mathrm{mL}^{-1}\right)$ for VAL, AML and HCT were prepared separately by dissolving appropriate amounts of respective drugs in methanol. These were diluted with methanol to obtain solutions of $10 \mu \mathrm{g} \mathrm{mL}^{-1}$ (VAL) and $1 \mu \mathrm{g} \mathrm{mL}^{-1}$ AML and HCT. The solutions were mixed and volumes were made up to $10 \mathrm{~mL}$ in volumetric flasks to get mixed aqueous solutions of $1-80 \mu \mathrm{g} \mathrm{mL}^{-1} \mathrm{VAL}, 0.12-4 \mu \mathrm{g} \mathrm{mL}{ }^{-1}$ AML and $0.1-8 \mu \mathrm{g} \mathrm{mL}^{-1} \mathrm{HCT}$.

\section{Calibration standards and QC samples}

Calibration standards (CS1-CS8) and QC samples were prepared as $5 \%$ spiked thawed plasma samples, to which the internal standard (IS) (telmisartan) aqueous solution $\left(10 \mu \mathrm{g} \mathrm{mL}^{-1}\right)$ was added. The solutions were vortexed for 1 minute and the final concentration range of 50-4000 ng mL $\mathrm{mL}^{-1} \mathrm{VAL}, 6-200 \mathrm{ng} \mathrm{mL}^{-1}$ AML and 5-400 $\mathrm{ng} \mathrm{mL}^{-1} \mathrm{HCT}$ in plasma was obtained. Three quality control samples LQC, MQC and HQC (150, 600 and $\left.3000 \mathrm{ng} \mathrm{mL}^{-1}\right)$ VAL, (18, 30 and $\left.150 \mathrm{ng} \mathrm{mL}^{-1}\right)$ AML, and $\left(15,60\right.$ and $\left.300 \mathrm{ng} \mathrm{mL}^{-1}\right) \mathrm{HCT}$ were also prepared. 
R. N. Sharma and S. S. Pancholi: Simple RP-HPLC method for determination of triple drug combination of valsartan, amlodipine and hydrochlorothiazide in human plasma, Acta Pharm. 62 (2012) 45-58.

\section{Plasma sample}

The plasma sample was prepared by adding $1 \mathrm{~mL}$ mixture of methanol/acetonitrile (50:50, $V / V)$ as a protein precipitating solvent. After adding $15 \mu \mathrm{L}$ of IS and vortexing for 3 minutes, the mixture was centrifuged at $10000 \mathrm{rpm}$ for 10 minutes. The supernatant was filtered in a glass tube to evaporate the solvent under nitrogen. Finally, dried residue was reconstituted with $0.5 \mathrm{~mL}$ mobile phase, filtered and transferred to the auto sampler glass vials for RP-HPLC analysis.

\section{Method validation}

The developed method was validated according to USFDA and EMEA bioanalytical guidelines $(16,17)$, for the parameters such as linearity, specificity, selectivity, sensitivity, precision, accuracy, stability and robustness.

Linearity. - Peak area ratios of analyte to IS vs. analyte concentration in the range 50-4000 ng mL-1 (VAL), 6-200 ng mL-1 (AML) and 5-400 ng mL ${ }^{-1}$ (HCT) were plotted. The slope, intercept and correlation coefficient were calculated for each standard line.

Specificity and selectivity. - Specificity and selectivity of the method were investigated by analyzing six different lots of blank plasma and the concentration of all three analytes at LQC level. Plasma samples were prepared as per the method described in the sample preparation section.

Sensitivity. - Sensitivity data was evaluated by analyzing six sets of matrix samples spiked with $50 \mathrm{ng} \mathrm{mL}^{-1}$ VAL, $6 \mathrm{ng} \mathrm{mL}^{-1}$ AML, $5 \mathrm{ng} \mathrm{mL}^{-1} \mathrm{HCT}$ (LLOQ), prepared by the procedure described for the QC sample preparation. The analyte area response at the LLOQ should be at least 5 times the blank response. Analyte calculated concentration should be identifiable and reproducible with a precision of $\leq 20.0 \%$ and accuracy of $80.0-120.0 \%$

Limit of detection and limit of quantitation. - The limit of detection $(L O D)$ and limit of quantitation $(L O Q)$ of the method were determined by the signal to noise ratio. The detection and quantitation limits were determined as the lowest concentration level resulting in the peak area of three times and ten times of the base line noise, respectively.

Precision. - To establish intra-day accuracy and precision, six replicates of each LLOQ, LQC, MQC and HQC samples of VAL, AML and HCT were analyzed in a single analytical run on the same day and on different days for inter-day different runs.

Extraction recovery. - The extraction efficiency of VAL, AML, HCT and IS were determined by comparing the peak areas measured after extraction of plasma samples in triplicate at three concentrations (LQC, MQC and HQC) with those found after direct injection of aqueous (un-extracted) samples into the chromatographic system at the same concentration levels.

Stability. - Sample stability in terms of short-term process stability and freeze-thaw stability were tested by analyzing QC samples of VAL, HCT, AML and IS at LQC and HQC levels while long-term stability was tested at LQC, MQC and HQC levels. The 
R. N. Sharma and S. S. Pancholi: Simple RP-HPLC method for determination of triple drug combination of valsartan, amlodipine and hydrochlorothiazide in human plasma, Acta Pharm. 62 (2012) 45-58.

freeze-thaw stability $\left(24 \mathrm{~h}\right.$ at $-20^{\circ} \mathrm{C}$ for three cycles), short-term or bench-top stability $\left(24 \mathrm{~h}\right.$, room temperature) and long-term stability $\left(7\right.$ days at $\left.-20^{\circ} \mathrm{C}\right)$ were calculated. The LQC and HQC samples were stored at $-15^{\circ} \mathrm{C}$ for $24 \mathrm{~h}$ to measure the stability of samples processed in the autosampler. Stock solutions of VAL, HCT, AML and IS $(100 \mu \mathrm{g}$ $\mathrm{mL}^{-1}$ ) were stored at room temperature for $24 \mathrm{~h}$ and at $2-8{ }^{\circ} \mathrm{C}$ for 7 days, and the stability was evaluated after analyzing them at the ULOQ level.

Robustness. - The robustness of the method was checked by evaluating the system suitability parameters obtained after small changes in the mobile phase composition, injection volume, flow rate and column temperature at three levels of analytes.

\section{Determination of VAL, AML and HCT in spiked human plasma}

Validated RP-HPLC method was applied to the analysis of processed plasma samples, spiked with VAL (50-4000 ng mL ${ }^{-1}$ ), AML (6-200 ng mL ${ }^{-1}$ ) and HCT (5-400 ng mL $\mathrm{mL}^{-1}$ ). Three different concentration samples other than quality control concentrations were prepared by spiking with VAL, AML, and HCT and the mean percentage recovery was calculated.

\section{RESULTS AND DISCUSSION}

\section{Method optimization}

Some important parameters, viz. $\mathrm{pH}(2-7)$ of the mobile phase, concentration of the acid or buffer (ammonium acetate and ammonium formate) solution, percentage and type of the organic modifier (acetonitrile and methanol), different columns (CN column, $\mathrm{C}_{8}$ and $\mathrm{C}_{18}$ ), flow rates ( 0.5 to $2.0 \mathrm{~mL} \mathrm{~min}^{-1}$ ) were attempted for good chromatographic separation of valsartan, amlodipine and hydrochlorothiazide and IS (telmisartan) individually. Trials have shown that the acidic mobile phase with a reverse phase $\mathrm{C}_{18}$ column gives symmetric and sharp peaks. For this reason, $10 \mathrm{mmol} \mathrm{L}^{-1}$ ammonium formate solution was preferred as acidic buffer solution. Methanol was not sufficient to resolve VAL, AML, HCT and IS, so acetonitrile was introduced for its high eluting power. When buffer $\mathrm{pH}$ was changed from 2.0 to 3.5 and from 7.0 to 3.5 , the resolution was much better with decreasing peak tailing. Initially, the isocratic mobile phase with different combinations of methanol, acetonitrile and buffer was tried but the best results were obtained by time programming (gradient mode) from $20 \%$ acetonitrile and $80 \%$ buffer to $70 \%$ acetonitrile and $30 \%$ buffer within 20 min with a $1 \mathrm{~mL} \mathrm{~min}^{-1}$ flow rate. Retention times under these conditions were 5.92, 11.61, 17.64 and 18.97 for HCT, AML, VAL and IS, respectively (Fig. 2). The $254 \mathrm{~nm}$ wavelength was set for the quantitative analysis of all drugs. Although high absorption was observed at the wavelength of $221 \mathrm{~nm}$ for all drugs, it was not selected due to increased interference of background noise.

Physicochemical properties and structural similarity prompted us to select telmisar$\tan$ as internal standard for this method. Looking towards the low $\log P$ value of analytes, we tried the protein precipitation method to extract VAL, AML and HCT along with IS (7). A combination of $50 \%$ methanol and $50 \%$ acetonitrile was selected because of the 
R. N. Sharma and S. S. Pancholi: Simple RP-HPLC method for determination of triple drug combination of valsartan, amlodipine and hydrochlorothiazide in human plasma, Acta Pharm. 62 (2012) 45-58.

high extraction power for VAL, AML and HCT and IS. In extracted samples, endogenous plasma components did not produce any interfering peaks within the retention time of the analytes and IS, as shown in Fig. 2.

\section{Method validation}

System suitability. - The system suitability test was an integral part of the chromatographic method development and was used to verify that the system was adequate for the analysis to be performed. The results obtained after six replicate injections of MQC were within the RSD of $15 \%$ for area ratios of VAL, AML and HCT to IS. The suitability of the chromatographic system was also demonstrated by the retention time, resolution, theoretical plate, tailing factor and capacity factor values (Table I).

Linearity. - Linearity was observed in the concentration range $50-4000 \mathrm{ng} \mathrm{mL}^{-1}$ for VAL, 6-200 ng mL ${ }^{-1}$ for AML and 5-400 ng mL ${ }^{-1}$ for HCT, indicating its suitability for analysis. Calibration curves depict excellent correlations for VAL $(R=0.9985 \pm 0.0002)$, $\operatorname{AML}(R=0.9964 \pm 0.0018)$ and HCT $(R=0.9971 \pm 0.0005)$ (Table II). The back calculated nominal concentration of calibrations standards was within the range of 98.8-112.3 (VAL), 98.7-103.6 (AML) and 98.7-114.8 \% (HCT).

Specificity and selectivity. - No endogenous source of interference was observed at the retention time of analytes in any of the six lots of plasma when compared to blank and QC samples. Typical chromatograms obtained from blank plasma and plasma sam-
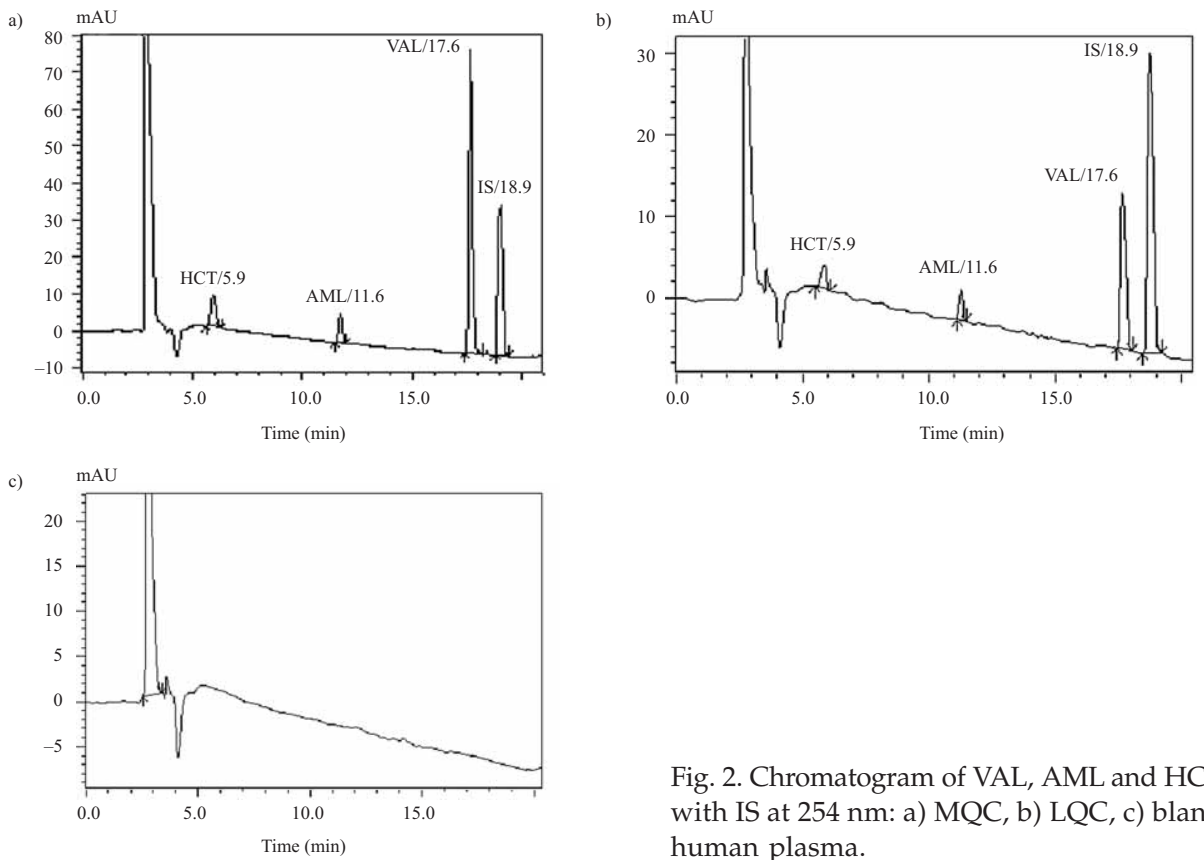

Fig. 2. Chromatogram of VAL, AML and HCT with IS at $254 \mathrm{~nm}$ : a) MQC, b) LQC, c) blank human plasma. 
R. N. Sharma and S. S. Pancholi: Simple RP-HPLC method for determination of triple drug combination of valsartan, amlodipine and hydrochlorothiazide in human plasma, Acta Pharm. 62 (2012) 45-58.

Table I. System suitability parameters

\begin{tabular}{lrrrr}
\hline Parameter & HCT & AML & VAL & \multicolumn{1}{c}{ IS } \\
\hline Retention time $\left(t_{\mathrm{R}}\right)(\mathrm{min})$ & 5.92 & 11.61 & 17.64 & 18.97 \\
Resolution $\left(R_{\mathrm{s}}\right)$ & 7.23 & 13.42 & 23.53 & 4.25 \\
Number of theoretical plates $(N)$ & 20589 & 45688 & 56725 & 52990 \\
Tailing factor $\left(T_{\mathrm{f}}\right)$ & 0.79 & 1.23 & 1.31 & 1.39 \\
Height equivalent to theoretical plate $(\mathrm{HETP})(\mu \mathrm{m})$ & 12.14 & 5.47 & 4.41 & 4.72 \\
Capacity factor $\left(k^{\prime}\right)$ & 1.14 & 3.21 & 5.39 & 5.87 \\
Selectivity $(\alpha)^{\mathrm{a}}$ & 2.82 & 1.68 & 1.09 & \\
Peak purity index $^{\mathrm{a}}$ & 1.000 & 0.999 & 0.999 & 1.000 \\
\hline
\end{tabular}

a With respect to succeeding peak.

ples containing LQC of VAL, AML and HCT are presented in Figs. $2 b$ and c. Also, the peak purity plot for VAL, AML, HCT and IS (Fig. 3) shows the peak purity index of nearly 1 for each (Table I) and no other peaks co-eluted with analyte.

Sensitivity. - The RSD and mean measured concentration at the LLOQ level were found to be 5.8 and $109.6 \%$ for VAL, 6.4 and $104.2 \%$ for AML and 6.7 and $109.3 \%$ for $\mathrm{HCT}$, respectively. The lowest concentrations of $20 \mathrm{ng} \mathrm{mL}^{-1}$ for VAL, $6 \mathrm{ng} \mathrm{mL}^{-1}$ for AML and $5 \mathrm{ng} \mathrm{mL}^{-1}$ for HCT were selected as $L O Q$. The LOD measured for this method was 7, 2 and $2 \mathrm{ng} \mathrm{mL}^{-1}$ for VAL, AML and HCT, respectively.

Accuracy and precision. - The accuracy and precision were suggested by means of the concentration found and RSD, respectively at four QC samples for VAL (50, 150, 600 and $\left.3000 \mathrm{ng} \mathrm{mL}{ }^{-1}\right)$, AML (6, 18, 30 and $\left.150 \mathrm{ng} \mathrm{mL}^{-1}\right)$ and $\operatorname{HCT}\left(5,15,60\right.$ and $\left.300 \mathrm{ng} \mathrm{mL}^{-1}\right)$ (Table III).

Table II. Linear regression data

\begin{tabular}{lccc}
\hline Concentration range $\left(\mathrm{ng} \mathrm{mL}^{-1}\right)$ & Slope $^{\mathrm{a}}$ & Intercept $^{\mathrm{a}}$ & Correlation coefficient $^{\mathrm{a}}$ \\
\hline Valsartan & & & \\
50-4000 & $0.028 \pm 0.002$ & $0.520 \pm 0.057$ & $0.9985 \pm 0.0002$ \\
& $(1.4)$ & $(10.9)$ & $(0.02)$ \\
\hline Amlodipine & & & \\
& & & $0.9964 \pm 0.0018$ \\
6-200 & $(17.2)$ & $(26.3)$ & $(0.2)$ \\
\hline Hydrochlorothiazide & & $0.003 \pm 0.0024$ & \\
5-400 & $0.012 \pm 0.001$ & $0.041 \pm 0.013$ & $0.9971 \pm 0.0015$ \\
\end{tabular}

a Mean \pm SD (RSD, \%), $n=5$. 
R. N. Sharma and S. S. Pancholi: Simple RP-HPLC method for determination of triple drug combination of valsartan, amlodipine and hydrochlorothiazide in human plasma, Acta Pharm. 62 (2012) 45-58.

a)

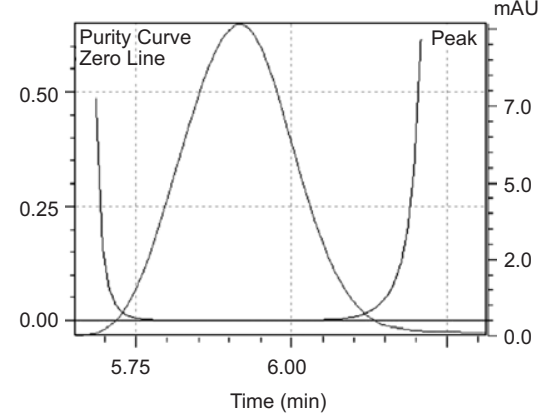

c)

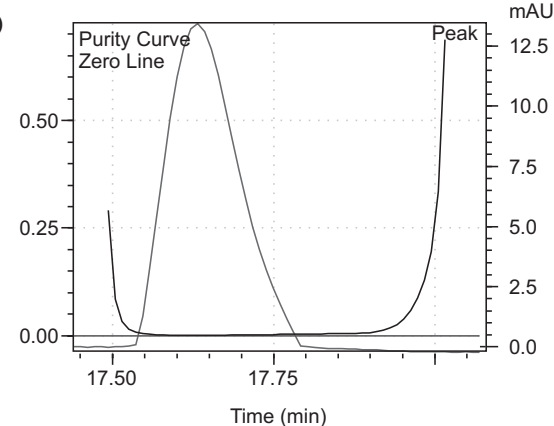

b)

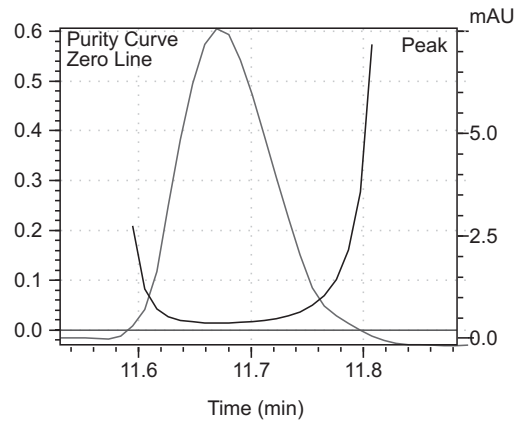

d)

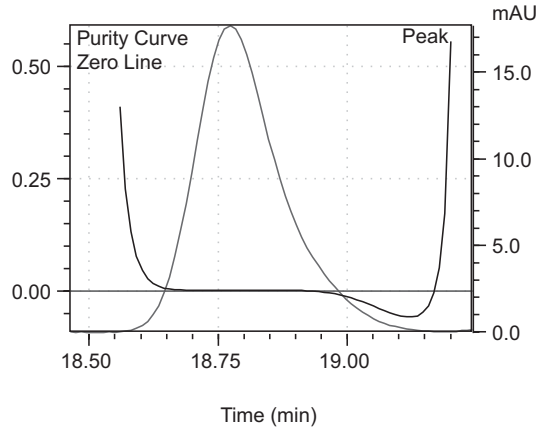

Fig. 3. Peak purity curve of: a) HCT, b) AML, c) VAL and d) IS by PDA detector.

The mean for intra- and inter-run accuracy ranged 101-108 and 102-108 \% for VAL, AML and HCT. RSD values for intra- and inter-run precision were 2-6 and 5-10\% (VAL), 6-8 and 9-12\% (AML) and 7-8 and 9-12\% (HCT). The across mean RSD and accuracy was 4.1 and $101.8 \%$ (VAL), 6.6 and $104.9 \%$ (AML) and 7.4 and $104.4 \%$ (HCT).

Extraction recovery. - The mean recovery \pm RSD across three concentrations of $76.5 \pm 2.1 \%$ (VAL), $72.0 \pm 5.2 \%$ (AML), $73.0 \pm 4.7 \%$ (HCT) and $73.4 \pm 5.1 \%$ for internal standard suggested good extraction recovery (Table IV).

Stability. - Stability tests of the analytes were designed to cover the expected conditions of handling clinical or preclinical samples (Table V). No significant loss of analytes in stock solution was observed when stored at room temperature and $2-8{ }^{\circ} \mathrm{C}$, respectively, and analyzed at the ULOQ level. Stock solutions of VAL, AML, HCT and IS were stable for at least 7 days and the mean change was less than $10 \%$. During withdrawal from the freezer and preparation, the samples were found stable with the mean concentration change of -0.8 (LQC) and $-0.2 \%$ (HQC) of VAL, -1.0 (LQC) and $-0.6 \%$ (HQC) of AML and, -1.0 (LQC) and $-0.9 \%$ (HQC) of HCT. The extracted drug samples were stable at $15{ }^{\circ} \mathrm{C}$ for at least $24 \mathrm{~h}$ in the autosampler. Mean changes of concentration values at LQC and HQC levels after the third cycle of freeze-thaw stability studies were -0.6 and -0.8 (VAL), -1.8 and -1.4 (AML) and -0.6 and $-1.8 \%$ (HCT). The QC samples were stable at $-20{ }^{\circ} \mathrm{C}$ for 7 days (long term); the results showed no significant loss of analytes. 
R. N. Sharma and S. S. Pancholi: Simple RP-HPLC method for determination of triple drug combination of valsartan, amlodipine and hydrochlorothiazide in human plasma, Acta Pharm. 62 (2012) 45-58.

Table III. Intra-day and inter-day precision and accuracy data

\begin{tabular}{|c|c|c|c|c|}
\hline \multirow{2}{*}{$\begin{array}{l}\text { Nominal conc. } \\
\qquad\left(\text { ng } m L^{-1}\right)\end{array}$} & \multicolumn{2}{|c|}{ Intra-day precision and accuracy } & \multicolumn{2}{|c|}{ Inter-day precision and accuracy } \\
\hline & 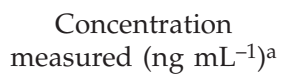 & Accuracy $(\%)^{\mathrm{a}}$ & 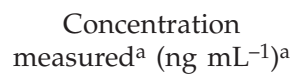 & Accuracy $(\%)^{\mathrm{a}}$ \\
\hline 50.00 & $53.51 \pm 2.94$ & $101.8 \pm 4.9$ & $51.66 \pm 5.09$ & $103.3 \pm 8.1$ \\
\hline 150.00 & $152.69 \pm 6.39$ & $101.8 \pm 3.2$ & $154.16 \pm 8.85$ & $102.8 \pm 4.9$ \\
\hline 600.00 & $606.68 \pm 17.47$ & $101.1 \pm 2.2$ & $615.65 \pm 37.23$ & $101.7 \pm 4.3$ \\
\hline 3000.00 & $3071.89 \pm 137.71$ & $102.4 \pm 4.6$ & $3054.69 \pm 175.08$ & $107.0 \pm 5.1$ \\
\hline Across mean & & $101.8 \pm 0.5$ & & $103.7 \pm 2.3$ \\
\hline \multicolumn{5}{|c|}{ Amlodipine } \\
\hline 6.00 & $6.53 \pm 0.49$ & $107.9 \pm 6.9$ & $6.47 \pm 0.76$ & $108.0 \pm 8.6$ \\
\hline 18.00 & $18.54 \pm 1.19$ & $103.0 \pm 5.8$ & $18.26 \pm 1.84$ & $101.5 \pm 7.4$ \\
\hline 30.00 & $31.57 \pm 2.12$ & $105.2 \pm 5.5$ & $31.32 \pm 3.01$ & $104.4 \pm 6.9$ \\
\hline 150.00 & $155.36 \pm 8.88$ & $103.6 \pm 4.2$ & $151.16 \pm 13.90$ & $103.8 \pm 6.3$ \\
\hline Across mean & & $104.9 \pm 2.2$ & & $104.4 \pm 2.7$ \\
\hline \multicolumn{5}{|c|}{ Hydrochlorothiazide } \\
\hline 5.00 & $5.23 \pm 0.42$ & $104.7 \pm 6.4$ & $5.22 \pm 0.61$ & $104.4 \pm 9.2$ \\
\hline 15.00 & $15.75 \pm 1.14$ & $105.1 \pm 5.1$ & $15.40 \pm 1.44$ & $102.7 \pm 7.1$ \\
\hline 60.00 & $62.93 \pm 4.19$ & $104.9 \pm 4.3$ & $62.35 \pm 3.36$ & $107.8 \pm 8.6$ \\
\hline 300.00 & $308.82 \pm 22.89$ & $102.9 \pm 6.3$ & $314.15 \pm 14.35$ & $104.8 \pm 7.5$ \\
\hline Across mean & & $104.4 \pm 1.0$ & & $104.9 \pm 2.1$ \\
\hline
\end{tabular}

a Mean $\pm \mathrm{SD}, n=6$.

Table IV. Extraction recovery data from human plasma

\begin{tabular}{lccc}
\hline Analyte & Nominal concentration $\left(\mathrm{ng} \mathrm{mL}^{-1}\right)$ & Recovery $(\%)$ & RSD $(\%)^{\mathrm{a}}$ \\
\hline Valsartan & 150.0 & 76.5 & 4.7 \\
& 600.0 & 74.9 & 3.2 \\
& 3000.0 & 78.1 & 7.7 \\
Amlodipine & Across mean & 76.5 & 2.1 \\
& 18.0 & 73.9 & 2.8 \\
& 30.0 & 67.7 & 8.3 \\
Hydrochlorothiazide & 150.0 & 74.3 & 8.4 \\
& Across mean & 72.0 & 5.2 \\
& 15.0 & 69.5 & 5.4 \\
IS & 60.0 & 76.4 & 4.4 \\
\hline
\end{tabular}

a $n=6$. 
R. N. Sharma and S. S. Pancholi: Simple RP-HPLC method for determination of triple drug combination of valsartan, amlodipine and hydrochlorothiazide in human plasma, Acta Pharm. 62 (2012) 45-58.

Table V. Stability data for valsartan, amlodipine and hydrochlorothiazide

\begin{tabular}{|c|c|c|c|c|}
\hline \multirow{2}{*}{ Storage condition } & \multirow{2}{*}{ Analyte } & \multirow{2}{*}{$\begin{array}{l}\text { Nominal concen- } \\
\text { tration }\left(\mathrm{ng} \mathrm{mL} \mathrm{mL}^{-1}\right)\end{array}$} & \multicolumn{2}{|c|}{ Concentration measured $(\%)^{\mathrm{a}}$} \\
\hline & & & Fresh & Stability \\
\hline \multirow{4}{*}{$\begin{array}{l}\text { Main stock solution } \\
\text { stability at RT for } \\
24 \mathrm{~h}\end{array}$} & VAL & 4000.0 & $101.4 \pm 2.1$ & $100.1 \pm 2.6$ \\
\hline & AML & 200.0 & $101.9 \pm 2.8$ & $100.8 \pm 3.1$ \\
\hline & $\mathrm{HCT}$ & 400.0 & $100.8 \pm 2.7$ & $99.8 \pm 3.1$ \\
\hline & IS & 1000.0 & $101.2 \pm 3.1$ & $100.1 \pm 1.7$ \\
\hline \multirow{4}{*}{$\begin{array}{l}\text { Main stock solution } \\
\text { stability at } 2-8^{\circ} \mathrm{C} \\
\text { for } 7 \text { days }\end{array}$} & VAL & 4000.0 & $102.3 \pm 2.4$ & $101.2 \pm 1.8$ \\
\hline & AML & 200.0 & $101.8 \pm 2.3$ & $100.9 \pm 2.7$ \\
\hline & $\mathrm{HCT}$ & 400.0 & $101.9 \pm 2.5$ & $100.9 \pm 2.4$ \\
\hline & IS & 1000.0 & $102.0 \pm 2.4$ & $101.2 \pm 1.8$ \\
\hline \multirow{6}{*}{$\begin{array}{l}\text { Bench top stability } \\
\text { at RT for } 24 \mathrm{~h}\end{array}$} & \multirow{2}{*}{ VAL } & 150.0 & $99.1 \pm 4.3$ & $98.3 \pm 5.1$ \\
\hline & & 3000.0 & $103.6 \pm 6.6$ & $103.4 \pm 7.2$ \\
\hline & \multirow{2}{*}{ AML } & 18.0 & $102.8 \pm 4.4$ & $101.7 \pm 3.1$ \\
\hline & & 150.0 & $99.3 \pm 4.7$ & $98.7 \pm 5.1$ \\
\hline & \multirow{2}{*}{$\mathrm{HCT}$} & 15.0 & $102.7 \pm 5.6$ & $101.7 \pm 6.8$ \\
\hline & & 300.0 & $99.8 \pm 3.3$ & $98.9 \pm 4.8$ \\
\hline \multirow{6}{*}{$\begin{array}{l}\text { Process stability at } \\
15^{\circ} \mathrm{C} \text { for } 24 \mathrm{~h}\end{array}$} & \multirow{2}{*}{ VAL } & 150.0 & $99.3 \pm 5.4$ & $98.8 \pm 5.8$ \\
\hline & & 3000.0 & $101.4 \pm 3.3$ & $100.7 \pm 4.9$ \\
\hline & \multirow{2}{*}{ AML } & 18.0 & $102.2 \pm 4.3$ & $102.3 \pm 2.2$ \\
\hline & & 150.0 & $99.8 \pm 0.6$ & $100.0 \pm 0.7$ \\
\hline & \multirow{2}{*}{$\mathrm{HCT}$} & 15.0 & $101.0 \pm 5.6$ & $100.8 \pm 6.4$ \\
\hline & & 300.0 & $99.8 \pm 3.1$ & $99.1 \pm 3.9$ \\
\hline \multirow{6}{*}{$\begin{array}{l}\text { Freeze thaw at } \\
-20{ }^{\circ} \mathrm{C} \text { for } 24 \mathrm{~h} \\
\text { (three cycles) }\end{array}$} & \multirow{2}{*}{ VAL } & 150.0 & $98.7 \pm 3.7$ & $98.1 \pm 4.6$ \\
\hline & & 3000.0 & $102.5 \pm 3.9$ & $101.8 \pm 5.1$ \\
\hline & \multirow{2}{*}{ AML } & 18.0 & $102.6 \pm 4.3$ & $100.7 \pm 4.7$ \\
\hline & & 150.0 & $100.3 \pm 3.9$ & $98.9 \pm 4.5$ \\
\hline & \multirow{2}{*}{ НCT } & 15.0 & $102.5 \pm 4.5$ & $101.9 \pm 5.1$ \\
\hline & & 300.0 & $102.6 \pm 4.3$ & $100.7 \pm 4.7$ \\
\hline \multirow{9}{*}{$\begin{array}{l}\text { Long term stability } \\
\text { at }-20{ }^{\circ} \mathrm{C} \text { for } 7 \text { days }\end{array}$} & \multirow{3}{*}{ VAL } & 150.0 & $100.9 \pm 3.8$ & $99.9 \pm 5.0$ \\
\hline & & 600.0 & $99.5 \pm 3.0$ & $99.3 \pm 3.7$ \\
\hline & & 3000.0 & $101.4 \pm 3.3$ & $100.9 \pm 4.2$ \\
\hline & \multirow{3}{*}{ AML } & 18.0 & $99.9 \pm 3.8$ & $99.3 \pm 2.7$ \\
\hline & & 30.0 & $104.9 \pm 1.0$ & $104.3 \pm 4.1$ \\
\hline & & 150.0 & $100.4 \pm 3.3$ & $99.6 \pm 3.0$ \\
\hline & \multirow{3}{*}{$\mathrm{HCT}$} & 15.0 & $101.7 \pm 3.7$ & $101.1 \pm 6.9$ \\
\hline & & 60.0 & $101.1 \pm 5.8$ & $101.2 \pm 7.0$ \\
\hline & & 300.0 & $101.2 \pm 5.6$ & $100.4 \pm 7.4$ \\
\hline
\end{tabular}

a Mean \pm SD, $n=6$.

RT - room temperature 
R. N. Sharma and S. S. Pancholi: Simple RP-HPLC method for determination of triple drug combination of valsartan, amlodipine and hydrochlorothiazide in human plasma, Acta Pharm. 62 (2012) 45-58.

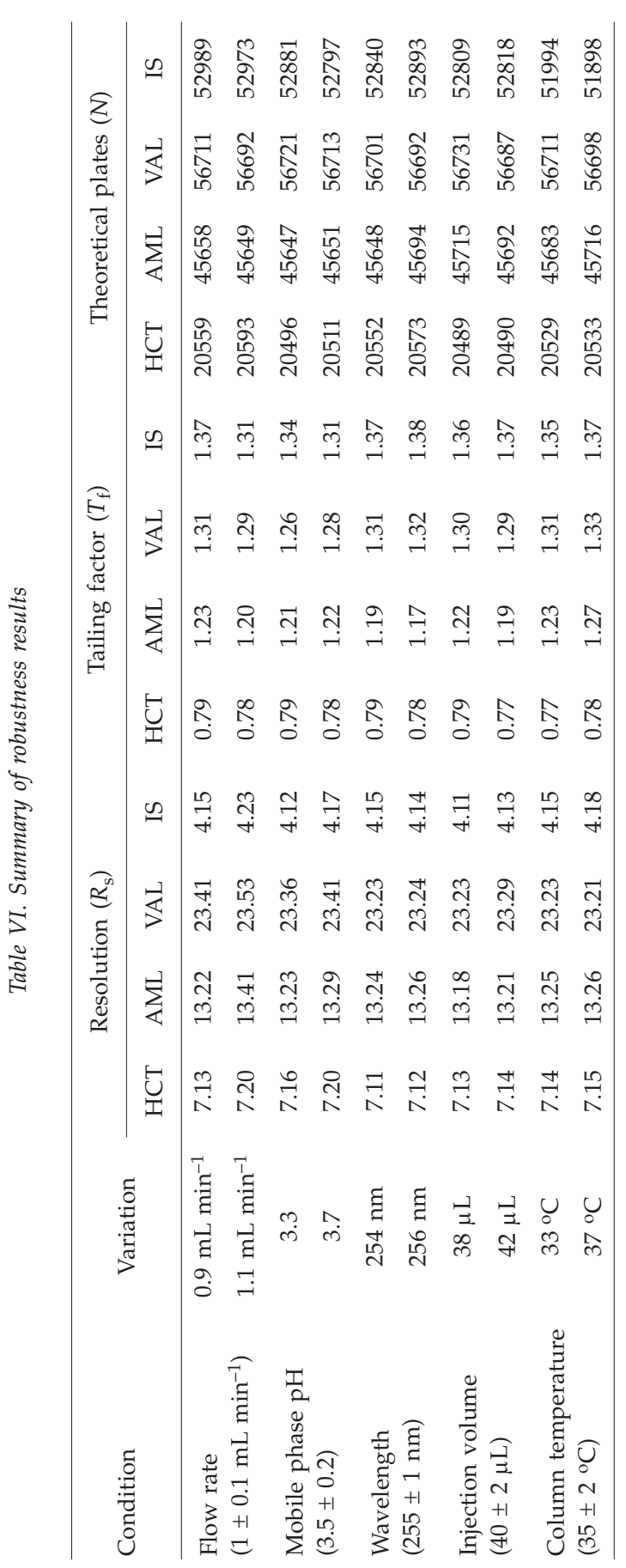


R. N. Sharma and S. S. Pancholi: Simple RP-HPLC method for determination of triple drug combination of valsartan, amlodipine and hydrochlorothiazide in human plasma, Acta Pharm. 62 (2012) 45-58.

Robustness. - To determine the robustness of the developed method, mobile phase $\mathrm{pH}$, mobile phase gradient acetonitrile to buffer, flow-rate of mobile phase detection wavelength, injection volume and column temperature were deliberately altered and the responses for VAL, AML and HCT were recorded. None of the modifications caused a significant change in resolution between analytes, tailing factor and theorectical plates (Table VI).

\section{Determination of VAL, AML and HCT in spiked human plasma}

The across mean recovery of three replicates of spiked plasma samples of 100, 400 and 1000 VAL, 8, 20 and 80 AML and 10, 40 and 100 HCT was calculated to be $98.2 \pm 6.6$, $97.6 \pm 3.7$ and $97.4 \pm 6.4 \%$, respectively. The results of the study indicate that the method is suitable for the assay of VAL, AML and HCT without any interference from the human plasma components.

\section{CONCLUSIONS}

In the present work, a simple, rapid and sensitive reversed phase HPLC method has been developed and validated for simultaneous estimation of the triple combination of VAL, AML and HCT in human plasma using a PDA detector. Validated method was found to be accurate, precise and specific. Simple and reproducible sample extraction procedure with the mixture of acetonitrile/methanol (50:50) offers acceptable recovery for the drugs. Stability data shows that analytes were stable in short and long studies; seven days (long term) was sufficient for the preliminary pharmacokinetic study of VAL, AML and HCT. The LC-MS/MS method is obviously highly sensitive but the analysis done by HPLC is suitable for the preliminary pharmacokinetic study. Detection of VAL, AML and HCT at higher to moderate levels can be performed by this method and it can be also used for guidance to the LC-MS/MS method.

Acknowledgements. - The authors thank Dr. Reddy's Laboratory and Torrent Pharma Ltd. for providing gift samples for this project.

\section{REFERENCES}

1. N. Koseki, H. Kawashita, H. Hara, M. Niina, M. Tanaka, R. Kawai, Y. Nagae and N. Masuda, Development and validation of a method for quantitative determination of valsartan in human plasma by liquid chromatography-tandem mass spectrometry, J. Pharm. Biomed. Anal. 43 (2007) 1769-1774; DOI: 10.1016/j.jpba.2006.12.030.

2. M. Doménech and A. Coca, Role of triple fixed combination valsartan, amlodipine and hydrochlorothiazide in controlling blood pressure, Patient Pref. Adh. 4 (2010) 105-113.

3. The Merck Index (Ed. S. Budavari), 13th ed. Merck \& Co. Inc., Whitehouse Station (NJ) 2001.

4. N. Daneshtalab, R. Z. Lewanczuk and F. Jamali, High-performance liquid chromatographic analysis of angiotensin II receptor antagonist valsartan using a liquid extraction method, J. Chromatogr. B. 766 (2002) 345-349; DOI: 10.1016/S0378-4347(01)00507-2. 
R. N. Sharma and S. S. Pancholi: Simple RP-HPLC method for determination of triple drug combination of valsartan, amlodipine and hydrochlorothiazide in human plasma, Acta Pharm. 62 (2012) 45-58.

5. E. K. Schmidt, K. H. Antonin, G. Flesch and A. Racine-Poon, An interaction study with cimetidine and the new angiotensin II antagonist valsartan, Eur. J. Clin. Pharmacol. 53 (1998) 451-458; DOI: $10.1007 / \mathrm{s} 002280050406$.

6. F. Waldmeier, G. Flesch, P. Muller, T. Winkler, H. P. Kriemler, P. Buhlmayer and M. De Gasparo, Pharmacokinetics, disposition and biotransformation of [14C]-radiolabelled valsartan in healthy male volunteers after a single oral dose, Xenobiotica 27 (1997) 59-71; DOI: 10.1080/004982597240767.

7. P. Pickkers, A. D. Hughes, F. G. M. Russel, T. Thien and P. Smits, Thiazide-induced vasodilation in humans is mediated by potassium channel activation, Hypertension 32 (1998) 1071-1076.

8. S. G. Chrysant, Fixed low-dose drug combination for the treatment of hypertension, Arch. Fam. Med. 7 (1998) 370-376; DOI: 10.1001/archfami.7.4.370.

9. J. Macek, J. Kl'1ma and P. Ptácek, Rapid determination of valsartan in human plasma by protein precipitation and high-performance liquid chromatography, J. Chromatogr. B 832 (2006) 169-172; DOI: $10.1016 /$ j.jchromb.2005.12.035.

10. B. Koçyiğit-Kaymakçoğlu, S. Unsalan and S. Rollas, Determination and validation of ketoprofen, pantoprazole and valsartan together in human plasma by high performance liquid chromatography, Pharmazie 61 (2006) 586-589.

11. Zarghi, S. M. Foroutan, A. Shafaati and A. Khoddam, Validated HPLC method for determination of amlodipine in human plasma and its application to pharmacokinetic studies, Farmaco 60 (2005) 789-792; DOI: 10.1016/j.farmac.2005.06.012.

12. R. V. S. Nirogi, V. N. Kandikere, K. Mudigonda, M. Shukla and S. Maurya, Sensitive and rapid liquid chromatography/tandem mass spectrometry assay for the quantification of amlodipine in human plasma, Biomed. Chromatogr. 20 (2006) 833-842; DOI: 10.1002/bmc.600.

13. L. Li, J. Sun, P. Yang and Z. He, Liquid chromatography-electrospray ionization mass spectrometric method for the determination of hydrochlorothiazide in human plasma: application to a pharmacokinetic study, Anal. Lett. 39 (2006) 2797-2807; DOI: 10.1080/00032710600867465.

14. H. Li, Y. Wang, Y. Jiang, Y. Tang, J. Wang, L. Zhao and J. Gu, A liquid chromatography/tandem mass spectrometry method for the simultaneous quantification of valsartan and hydrochlorothiazide in human plasma, J. Chromatog. B 852 (2007) 436-442; DOI: 10.1016/j.jchromb.2007.02. 014.

15. M. Çelebier, M. S. Kaynak, S. Altınöz and S. Şahin, Validated HPLC method development: the simultaneous analysis of amlodipine and valsartan in samples for liver perfusion studies, $\mathrm{Ha}$ cettepe Univ. J. Fac. Phar. 28 (2008) 15-30.

16. FDA, Guidance for Industry, Bioanalytical Method Validation, U.S. Department of Health and Human Services, FDA, CDER and CVM, Rockville 2001.

17. EMEA, Draft Guidelines on Validation of Bioanalytical Methods, Committee for Medicinal Products for Human Use, EMEA, London 2009. 
R. N. Sharma and S. S. Pancholi: Simple RP-HPLC method for determination of triple drug combination of valsartan, amlodipine and hydrochlorothiazide in human plasma, Acta Pharm. 62 (2012) 45-58.

\section{$S A \check{Z} E T A K$}

\section{Jednostavna RP-HPLC metoda za određivanje kombinacije triju lijekova valsartana, amlodipina i hidroklorotiazida u humanoj plazmi}

RITESH N. SHARMA i SHYAM SUNDER PANCHOLI

U ovom radu opisana je i validirana jednostavna RP-HPLC metoda za određivanje valsartana (VAL), amlodipina (AML) i hidroklorotiazida (HCT) u humanoj plazmi. VAL, AML i HCT su razlučeni na koloni Gemini $\mathrm{C}_{18}$. Početni sastav mobilne faze bio je acetonitril $(20 \%)$ i $10 \mathrm{mmol} \mathrm{L}^{-1}$ otopina amonijevog formijata $(80 \%, V / V$, pH podešen na $3,5 \pm 0,2$ pomoću mravlje kiseline), a nakon 20 minuta $70 \%$ acetonitrila i $30 \% 10 \mathrm{mmol} \mathrm{L}^{-1}$ amonijevog formijata, uz protok od $1 \mathrm{~mL} \mathrm{~min}^{-1}$. Uzorci su pročišćeni taloženjem proteina i ekstrakcijom. Telmisartan je upotrebljen kao unutarnji standard. Metoda je validirana prema uputama USFDA i EMEA uz dobro reproducibilnost i linearnost: $R=0.9985$ (VAL), 0.9964 (AML), and 0.9971 (HCT). Ponovljivost i intermedijarna preciznost bile su u rasponu 2,2-8,1, odnosno 4,6-11,7 \% za sve tri ljekovite tvari. Srednji povrat ekstrakcije iz humane plazme za ovu kombinaciju lijekova iznosila je 76,5 (VAL), 72,0 (AML) i 73,0 (HCT) \%. Iako je LC-MS/MS metoda osjetljivija od HPLC metode, HPLC je prihvatljiva za preliminarna farmakokinetička ispitivanja. Provedeni pokusi pokazuju da se predloženom metodom mogu simultano odrediti sastavnice trostruke kombinacije lijekova u humanoj plazmi. Predložena metoda može biti korisna smjernica za LC-MS/MS metodu.

Ključne riječi: valsartan, amlodipin, hidroklorotiazid, RP-HPLC, taloženje proteina, kombinacija tri lijeka

S. K. Patel College of Pharmaceutical Education and Research, Ganpat University, Mahesana-Gozaria Highway, Kherva Dist. Mahesana-382711, Gujarat, India

Babria Institute of Pharmacy, Varnama, Vadodara-391240, Gujarat, India 